\title{
correspondence
}

\section{Jobs gloom: a military solution?}

SIR, - The problems of job opportunities and job security in science are serious (21/28 December, page 743$)$. But solutions which may be highly desirable for individuals may be disastrous for science itself. While there are many exceptions, for most scientists the decline in research productivity between the years of 35 and 45 is unequivocal. Unfortunately this decline is only rarely matched by a compensating increase in teaching or administrative skills.

Although it may be anathema to most scientists to look to the military for an answer, I suggest that in this area it has much to teach us. Anyone becoming an army officer accepts that the career grade is Major and that, depending on the country concerned, those who are not promoted above this grade will retire between 40 and 45 . Each level of promotion buys a few extra years until Field Marshals are appointed for life. A similar system in science would provide a long term solution to the present ills. It would work as follows.

Far more junior posts than are at present available would be created but these would automatically terminate at age 40. A gratuity equal to three years salary or a modest pension would then be provided. Retirement could be taken as early as 35 when a one year gratuity would be given.

Promotion above the basic career grade would depend on a realistic assessment of research, teaching and administrative contributions. Each promotion rung would buy an extra five years. Perhaps half the entry would be eliminated at the first hurdle and another half at the second, with relatively little attrition thereafter. The few highly productive scientists who remain active into old age would become 'Field Marshals' and would not be expected to retire.

The advantages of this system are many. As in the army, people would enter science knowing that unless they did very well their career would end at 40 . This would eliminate the unenthusiastic at the beginning and provide a notable stimulus to research. Many junior posts would be available and the system would not be wrecked by a preponderance of individuals making little or no contribution. Institutions would not be reluctant to make early appointments for fear of having to maintain a person's employment until 65 or 70 . In most cases scientists would know by the age of 35 whether or not they were going to be successful and could then begin to plan second careers in the comfortable knowledge that they would have three years in which to make adjustments. As with the military, organisations would develop which specialised in placing scientists in appropriate positions in industry or government. Industry, government, and hence science would all benefit from this influx of people with a genuine scientific background and not simply a first degree in science.

I do not underestimate the anguish such a system would cause in the transition period. But some such radical approach is essential if we are not to replace the current problems of individuals by the much more serious one of an almost totally stagnant scientific community. Yours faithfully, DAVID F. HORROBIN

Clinical Research Institute,

Montreal, Canada

\section{No rabies virus at Glasgow}

SIR,-I should be grateful for the opportunity of correcting an error which has appeared in your journal (11 January, page 81 ). This was a statement in which the Department of Virology at the University of Glasgow was cited as a laboratory holding a Category A Pathogen, namely rabies, as at 12 December 1978 .

This, I am happy to tell you, is not the case, as the small stock of rabies virus held by that department was destroyed in June 1977. It had, in fact, never been used for active research, and had remained in deep freeze for eight years before being destroyed.

I imagine that your source of information for this article was the draft of the Shooter report. I am informed by the Scottish Home and Health Department that they anticipate being able to update and correct this situation before the report is finally published.

$$
\text { ANDREW D. RANKINE }
$$$$
\text { Your faithfully, }
$$

Court Offices,

University of Glasgow, UK

\section{Reassess hazards of recombinant DNA}

SIR,-The comments (15 February, page 509 ) by a committee of the Royal Society on the recent published statement of the Genetic Manipulation Advisory Group will be widely welcomed and supported. However, I should like to comment on one of the suggestions they make.

It is argued that there is an urgent need for more research to evaluate the risks associated with the ingestion of organisms containing recombinant DNA. Before devoting yet more resources to the general hypothesis that recombinant DNA synthesised in vitro poses novel hazards to man, is there not a prior need to reconsider in which areas of recombinant DNA research there remain sound arguments indicating that the hypothesis should be taken seriously? The committee has properly criticised the Genetic Manipulation Advisory Group for publishing what are of ten called hazard scenarios without adequate argument or evidence supported by citation of relevant literature. But could not a similar criticism be made with equal validity against the hazards hypothesis in its entirety? The report of the working party chaired by Lord Ashby which was set up to evaluate this hypothesis made a number of assertions in favour of it but none of them was documented in the way the Royal Society committee advocates. Admittedly this report was written when responses to the possibilities suggested in the Berg letter were more emotional than rational. All the more reason, now that four years have passed, for a cool reassessment of the questions before we embark on experimentation

The most urgent need in 1979 surely is for a re-examination of the hazards hypothesis to determine which, if any, aspects of it remain credible enough to deserve further attention on scientific grounds. This reassessment can only begin if those who remain convinced of hazards are prepared to state their case in published form with the rigour urged by the Royal Society committee, and in a manner that permits rebuttal like any other scientific argument.

If such a reassessment suggests that areas of significant risk remain then let us devote resources to quantifying the risks in these areas. If, on the other hand, this reassessment suggests that the hypothesis is unfounded or if no one is prepared to argue the case to the contrary, then should not those biologists who have collectively exploited their authority to open the so-called debate on the hazards of genetic engineering be urged to use their authority to close it in like manner. The danger in what the Royal Society proposes is that it could lend further weight to a hypothesis that may not deserve it.

$$
\begin{aligned}
& \text { Yours faithfully, } \\
& \text { R. H. PRITCHARD }
\end{aligned}
$$

Department of Genetics.

University of Leicester, $U K$.

\section{Energy forecasts mislead}

SIR,---Your discussion of energy forecasts (18 January, page 162) misses the point. It is easy to forecast a low consumption of energy, and all too easy to make this forecast come true. The price of nuclear powered electricity has risen partially because of delays caused by those predicting low consumption of energy; as a result, demand has fallen. In a recent visit to England I noted that the head of a small college lived in a house I rejected as unsuitable as a research lecturer in 1952. This contraction in housing standards, and with it a contraction in demand for fuel, has reached other parts of society in the past few years.

The challenge is not to predict a low energy consumption and make it come true; but to work toward a just society, where the well being and convenience we have of ten correlated with energy consumption can be achieved with minimum financial, ecological and environmental costs. None of these costs have a one-to-one relationship with energy production or consumption, and to argue otherwise may be counter-productive.

Those energy producers who concentrate solely on meeting "demand" have led us astray. Those who, like Mr Leach, are constantly trying to tell us that we don't need as much are equally guilty of keeping our concentration in the wrong place. Yours faithfully, RICHARD WILSON

Energy and Environmental

Policy Center,

Harvard University,

Cambridge, Ma., USA 